\title{
Growth factors in mammary gland function
}

\author{
Isabel A. Forsyth \\ AFRC Institute for Grassland and Animal Production, Hurley, near Maidenhead, \\ Berks SL6 5LR, UK
}

Keywords: mammary gland; cell culture; insulin-like growth factors; epidermal growth factor

\section{Introduction}

Production of colostrum and milk in adequate quantities is essential for the survival of the young of most mammals. Preparation of the mammary gland for lactation takes place throughout fetal and post-natal life and results from many complex interactions. It involves the transformation of the gland from an epithelial anlagen in the fetus, through formation of a branched tubular structure to the fully developed lobulo-alveolar gland which has acquired the differentiated capacity to produce milk proteins, fat and sugar and, by milk ejection, to deliver these to the suckling. Mammary development has been reviewed extensively (see Cowie et al., 1980; Mepham, 1983; Knight, 1984; Tucker, 1987, for recent reviews and further references).

The yield of the mammary gland is determined by numbers of epithelial cells and by their ability to transport, synthesize and secrete milk components. The balance between cell number and the secretory capacity of cells or alveolar units determines the shape of the lactation curve (Knight \& Wilde, 1987). This is in part determined by systemic endocrine factors but it is increasingly evident that there is a large measure of local control.

\section{Methods of study}

Many methodologies have been used to study the mammary gland. The stimulus has been both interest in lactation as part of the reproductive cycle and also the relative accessibility of mammary tissue. Because much of its development occurs into adult life, the mammary gland is an excellent model for the cell biology of normal and neoplastic growth and of differentiation.

\section{Endocrine organ ablation and replacement therapy}

This has been the classical approach to the study of mammary development. It has established the importance of hormones from the ovary, adrenal, pituitary and placenta acting systemically in bringing about the different phases of mammary growth and function. Sequential administration of combinations of steroid and protein hormones can mimic the development occurring through puberty, first pregnancy and into lactation in rats (Lyons, 1958) and mice (Nandi, 1959) that have been ovariectomized, adrenalectomized and hypophysectomized. The number of species in which it is practicable to apply such methods is, however, strictly limited and it is not possible to conclude whether hormones are acting directly, or indirectly via hormone-dependent factors produced in the mammary gland or another tissue. One of the concerns in earlier studies of this type was whether the metabolic status of endocrinectomized animals was adequately restored (Jacobsohn, 1961). 


\section{Transplantation}

Studies in mice have shown that mammary epithelium can be transplanted into mammary fat pads previously cleared by destruction of the mammary rudiment (DeOme et al., 1959) or into other subcutaneous or intra-abdominal fat deposits (Hoshino \& Martin, 1974). It will not proliferate in sites which do not provide a matrix of white adipose tissue.

The athymic mouse can accept transplants of mammary tissue from other species without rejection. Human (Soule \& McGrath, 1980; McManus \& Welsch, 1984) and bovine (Sheffield \& Welsch, 1986) mammary tissue have been studied by this method.

\section{Local hormone administration}

Test materials can be applied directly to mammary tissue in vivo to study local effects. Methods which have been used include local injection either subcutaneously over the gland or into the gland via the teat (Lyons, 1942) and the use of slow release implants (Silberstein \& Daniel, 1987).

\section{Culture in vitro}

The ability to sustain growth and development of mammary tissue in culture in defined conditions has provided a powerful tool in the study of regulation. The mouse mammary gland was one of the first organs to be successfully cultured, as explants, in serum-free conditions (Rivera \& Bern, 1961) in medium supplemented with insulin + cortisol for optimal survival, plus prolactin (and/or growth hormone in the original studies) to induce or maintain secretory activity.

Perhaps closest to the in-vivo situation in that normal relationships between epithelium and stroma are maintained in full is the culture of whole glands, within the mammary fat pad (Ichinose \& Nandi, 1966; Banerjee \& Antoniou, 1984). There is, however, a strict limit to the size of glands that can be maintained in this way. Responses in vitro of ten require in-vivo priming of the donor animal by exogenous or endogenous hormones, making it difficult to separate in-vivo carry-over effects from the influence of in-vitro treatments.

In recent years, there have been dramatic improvements in methods of mammary cell culture. The early experience of growing isolated epithelial cells on plastic was disappointing in terms of studying control of either growth or differentiation. A significant breakthrough was the use by Emerman \& Pitelka (1977) of rat tail collagen as a substratum for isolated mouse mammary cells. Following cell attachment, the gels were released; contracted by attached cells, the collagen formed a floating raft on which the cells were polarized and showed morphological and biochemical markers of differentiation in a suitable hormonal environment (Emerman et al., 1977). Proliferation of epithelial cells can also be studied on attached collagen gels before confluence is attained (Mackenzie et al., 1982) and by embedding cells in collagen when branching duct-like structures form (Yang et al., 1980; Imagawa et al., 1982; McGrath, 1987). Other recently developed methods include the use of feeder layers of 3T3-L1 adipocytes (Levine \& Stockdale, 1984) and extracellular matrix extracted from mammary tissue (Wicha et al., 1982). These studies emphasize the requirements of mammary tissue for cell-cell interactions and for an appropriate substratum, reconstructing the in-vivo association between epithelium and stroma. Insoluble components of the extracellular matrix (laminin, type IV collagen, heparan sulphate proteoglycan; see Parry et al., 1987) and diffusible paracrine growth factors (see Oka \& Yoshimura, 1986) are probably involved.

Because of their homogeneous nature, cell lines which retain at least some of the properties of the mammary tissue from which they were derived have considerable experimental value. Many clonal lines have been established from mammary tumours (see Dickson \& Lippman, 1987, for examples of human breast cancer cell lines). Subculture of normal human mammary tissue obtained at reduction mammoplasty has been achieved by very careful attention to the medium requirements of the cells (Hammond et al., 1984; see also Bettgar \& McKeehan, 1986). Responses of all tissue in vitro, but especially of cell lines, must be interpreted with caution because of the 
tendency to lose hormonal responsiveness by selective receptor loss and because transformation may occur. Even primary cultures of mammary cells show abnormal patterns of secreted proteins in response to hormones in vitro and protein secretion is markedly influenced by the substratum (Lee et al., 1984).

\section{Classical hormones and the mammary gland: direct or indirect effects?}

Table 1 summarizes the minimal exogenous hormonal combinations needed to bring about the different phases of mammary development in ovariectomized, adrenalectomized and hypophysectomized rats. The roles of prolactin and growth hormone (GH) may be partly taken over during pregnancy in some species by placental lactogen (Forsyth, 1986; Thordarson \& Talamantes, 1987). Thyroid hormones regulate lobulo-alveolar development in the mouse (Vonderhaar \& Greco, 1979). There are species differences in requirements, especially for the maintenance of lactation. In ruminants, growth hormone, rather than prolactin, plays the dominant role (Johnsson \& Hart, 1986; Peel \& Bauman, 1987).

Table 1. Minimal hormonal requirements for mammary development in rats that have been adrenalectomized, ovariectomized and hypophysectomized (from Lyons, 1958)

\begin{tabular}{lll}
\hline Type of development & \multicolumn{1}{c}{$\begin{array}{c}\text { Physiological } \\
\text { state }\end{array}$} & \multicolumn{1}{c}{ Hormones } \\
\hline $\begin{array}{l}\text { Allometric duct growth, } \\
\text { end bud formation }\end{array}$ & Peripubertal & $\begin{array}{l}\text { Oestrogen }+ \text { adrenal } \\
\text { corticoid }+ \text { GH } \\
\text { Lobulo-alveolar growth }\end{array}$ \\
& Pregnancy & $\begin{array}{l}\text { Oestrogen }+ \text { progesterone }+ \\
\text { adrenal corticoid }+\end{array}$ \\
Milk secretion & Lactation & $\begin{array}{l}\text { Adrenal corticoid }+ \\
\text { prolactin }\end{array}$ \\
Milk ejection & Lactation & Oxytocin \\
\hline
\end{tabular}

A direct action of a hormone requires the presence of specific high affinity receptors. Mammary cells contain receptors for oestradiol, progesterone, glucocorticoids, thyroid hormone, oxytocin and prolactin but not apparently for GH (see Forsyth, 1983; Akers, 1985).

In considering differentiation, the action of hormones on the mammary gland appears to be largely direct. Prolactin plays a major role in activating transcription and translation of milk protein genes and the stabilization of messenger RNA. Glucocorticoids enhance the action of prolactin on transcription (see Houdebine et al., 1985; Rosen, 1987). Thyroid hormones synergize with prolactin with respect to $\alpha$-lactalbumin synthesis (see Topper \& Freeman, 1980). Insulin is essential for transcription of mouse and rat casein messenger RNA (Bolander et al., 1981; Chomczynski et al., 1984) but insulin-like growth factors can substitute in other roles, which require supraphysiological insulin concentrations in vitro (see below for further discussion).

To reconcile in-vivo and in-vitro findings on the biological actions of GH, Salmon \& Daughaday (1957) postulated that growth-promoting (mitogenic) actions of GH are brought about by secondary mediators, now identified as insulin-like growth factors (IGF-I and IGF-II; Daughaday et al., 1987). Prolactin and oestrogens are, like GH, clearly implicated in mammary growth from in-vivo studies, but it has similarly proved difficult to demonstrate unequivocally direct mitogenic actions of these hormones in vitro. 
Nicoll et al. (1987) have proposed the 'synlactin' hypothesis, suggesting that the growthpromoting actions of prolactin may result from a synergism between prolactin itself and prolactindependent synlactins produced by the liver and perhaps other tissues. They have demonstrated that media conditioned by liver slices from pregnant and lactating rats, but not male or virgin female rats, increase DNA synthesis in rat mammary explants.

To explore the apparent failure of oestrogen-responsive tumours to show increase in cell number in response to oestradiol in vitro, Sirbasku (1978) proposed the 'estromedin' hypothesis. Oestrogen-dependent factors which stimulated proliferation of mammary tumour cells were present in extracts of various rat tissues but the physiological significance of endocrine, oestrogeninduced mitogens remains to be determined. A major pituitary-derived mitogen has been identified as transferrin, that is an essential cell nutrient rather than a growth factor (Riss \& Sirbasku, 1987). At least part of the failure to detect mitogenic effects of oestradiol has been due to the almost ubiquitous use of phenol red as a pH indicator in culture medium. Berthois et al. (1986) showed that it acts as a weak oestrogen, mimicking, or masking, the mitogenic effects of added oestrogens. In phenol red-free medium, effects of oestradiol on DNA synthesis and cell proliferation can be observed (Table 2). Nevertheless, demonstration of an effect of oestradiol on cell proliferation in vitro does not provide proof that the hormone is acting directly. Acting via its receptor it might stimulate the release of an autocrine growth factor (Dickson et al., 1986). The possibility that oestrogens release target cells from inhibitory control has also been considered (Soto \& Sonnenschein, 1987).

Table 2. Effect of oestradiol on DNA synthesis (mean \pm s.e.m., $n=3$ ) by sheep mammary explants cultured for 6 days on Medium 199 without phenol red (S. J. Winder and I. A. Forsyth, unpublished)

\begin{tabular}{lc}
\hline $\begin{array}{l}\text { Oestradiol } \\
(\mathrm{pm})\end{array}$ & $\begin{array}{c}\text { DNA synthesis } \\
\left.\text { (d.p.m. } / \mu \mathrm{g} \text { DNA } \times 10^{-3}\right)\end{array}$ \\
\hline 0 & $6.4 \pm 0.5$ \\
1 & $12.8 \pm 0 \cdot 5$ \\
10 & $13.5 \pm 1 \cdot 0$ \\
\hline
\end{tabular}

The actions of $\mathrm{GH}$ on mammary growth and function are complex. Extensive studies of milk yield stimulation by recombinant GH in cattle (see Peel \& Bauman, 1987) indicate co-ordinated changes in many tissues. Actions at the mammary gland itself may well involve the insulin-like growth factors. Prosser et al. (1988) have shown that local infusion of IGF-I into goat mammary gland leads to increased milk secretion and mammary blood flow.

\section{Experimental evidence of growth factor effects on mammary gland}

Several putative uncharacterized growth factors for normal and neoplastic mammary cells have been proposed on the basis of activities present in tissue extracts and conditioned medium. These have been derived from non-mammary tissues, including pituitary and liver (endocrine) and from the mammary gland itself (paracrine or autocrine, associated respectively with mammary mesenchyme or epithelium (see Oka \& Yoshimura, 1986)). Until such factors are fully characterized, their status as cell nutrients or as polypeptide growth factors, acting at physiological concentrations via high affinity receptors to initiate DNA synthesis in quiescent cells, cannot be determined. Examples of tissue-derived mitogens which have been identified as cell nutrients are 
phosphoethanolanine from bovine pituitary (Kano-Sueoka et al., 1979) and transferrin from pig pituitaries (Riss \& Sirbasku, 1987). Beck \& Hosick (1988) have observed proliferation and improved epithelial morphology in cultures of mouse mammary epithelium in or on collagen in response to adipose tissue-conditioned medium. They suggest that unsaturated fatty acids may be responsible (see also Kidwell et al., 1982).

The alternative approach has been to examine the effects of purified or synthesized growth factors on mammary growth and differentiation. In some instances, generally with tumour cells, the two approaches have come together and it has been possible to identify active agents as known or new growth factors.

\section{Insulin-like growth factors}

The insulin-like growth factors (IGFs) form part of a family of structurally-related peptides which also includes proinsulin and relaxin (Blundell \& Humbel, 1980). They are potent mitogens for many cells. Human IGF-I is a basic polypeptide of 70 amino acid residues and is $\mathbf{G H}$ dependent. IGF-II, which shows much less GH dependence, is a neutral polypeptide of 67 amino acids. The structure of IGFs has been highly conserved (Daughaday et al., 1987). In circulation, IGFs are bound non-covalently to large molecular weight binding proteins. Predominant roles for IGF-I after birth and for IGF-II in the fetus have been postulated (Adams et al., 1983).

Table 3. Effect of insulin-like growth factor-I (IGF-I) on DNA synthesis (mean \pm s.e.m., $n=3$ ) by mammary epithelial cells prepared from a nonpregnant sheep and cultured on attached collagen gels for 5 days (S. J. Winder and I. A. Forsyth, unpublished)

\begin{tabular}{|c|c|}
\hline $\begin{array}{l}\text { IGF-1 } \\
(\mathrm{ng} / \mathrm{ml})\end{array}$ & $\begin{array}{c}\text { DNA synthesis } \\
\text { (d.p.m. } / \mu \mathrm{g} \mathrm{DNA} \times 10^{-3} \text { ) }\end{array}$ \\
\hline 0 & $27 \cdot 5 \pm 3 \cdot 3$ \\
\hline 1 & $54 \cdot 2 \pm 6 \cdot 7$ \\
\hline 10 & $99 \cdot 3 \pm 8 \cdot 5$ \\
\hline 100 & $126 \cdot 2 \pm 4 \cdot 6$ \\
\hline
\end{tabular}

Receptors for IGFs are of two types. The type 1 receptor is a heterotetramer, structurally homologous with the insulin receptor. It has a higher affinity for IGF-I than IGF-II and a low affinity for insulin. The type 2 receptor is a monomer, has a higher affinity for IGF-II than IGF-I and no significant affinity for insulin (Massague \& Czech, 1982). Binding of IGF-I with the characteristics of type 1 receptor has been detected in bovine (Campbell \& Baumrucker, 1986) and ovine (Winder \& Forsyth, 1987; Disenhaus et al., 1988) mammary gland. IGF-II binding has also been detected in ovine mammary gland, receptor numbers being greater than for IGF-I (Disenhaus et al., 1988). Breast cancer cell lines show receptors for both IGF-I and IGF-II and these appear similar in structure to the type 1 and type 2 receptors of other tissues (Furlanetto \& DiCarlo, 1984; Myal et al., 1984; DeLeon et al., 1988).

Mitogenic effects of IGF-I have been shown in cultures of normal mammary cells and breast cancer cell lines. Sheep mammary cells grown in phenol red-containing medium on attached collagen gels respond to IGF-I over the dose range $1-100 \mathrm{ng} / \mathrm{ml}$ and do not require the presence of any other added mitogen to produce this effect (Winder \& Forsyth, 1986; Table 3). Mouse mammary epithelial cells in collagen increase cell number in response to IGF-I, but epidermal growth factor (EGF) is also required (Imagawa et al., 1986). IGF-I stimulates DNA synthesis in human breast cancer cell lines in vitro (Furlanetto \& DiCarlo, 1984; Myal et al., 1984), as well as tumour formation by human MCF-7 cells in vivo in athymic mice (Dickson et al., 1986). 
Sheep mammary cells show little response to IGF-II in vitro (Winder \& Forsyth, 1986) but the T-47D human breast cancer cell line grows in response to rat IGF-II (Myal et al., 1984). Dembinski et al. (1985) have identified an oestrogen-potentiating factor of pituitary origin which stimulates the growth of oestrogen-responsive human breast cancer cells in the presence of oestradiol and appears to be immunologically related to IGF-II (Dembinski \& Shiu, 1987).

Human breast cancer cell lines synthesize and secrete IGF-I. This has been demonstrated by radioimmunoassay, partial purification and the presence of messenger RNAs (see Dickson \& Lippman, 1987). Messenger RNA for IGF-I but not IGF-II has been demonstrated at low levels in normal rat mammary gland (Murphy et al., 1987). Oestradiol and insulin stimulate IGF-I production in MCF-7 cells in phenol red-free media (Dickson \& Lippman, 1987).

Some of the reported effects of insulin on mammary tissue may be mediated via cross-reaction with the type 1 receptor. This would explain the supraphysiological concentrations of insulin $\left(\sim 10^{-6} \mathrm{M}\right)$ which are generally found to be necessary to stimulate cell replication in mammary explants (Stockdale et al., 1966; Skarda et al., 1977) and to potentiate maximally the effects of prolactin on lactogenesis in vitro (Houdebine et al., 1985). It would also explain why diabetic animals show no significant impairment of mammary growth (Norgren, 1968; Topper \& Freeman, 1980). In addition to effects on cell replication, Prosser \& Topper (1986) have shown that IGF-I can substitute for insulin, in increasing the basal rate of carrier-mediated glucose transport by mouse mammary explants in vitro to rates seen in early lactation. Nevertheless, insulin receptors have been demonstrated in mammary tissue (Posner et al., 1974; Campbell et al., 1987). In sheep mammary cells insulin stimulates DNA synthesis even at very low concentrations (S. J. Winder \& I. A. Forsyth, unpublished results). Insulin cannot be effectively replaced by IGF-I or EGF for milk protein gene expression (Bolander et al., 1981; Chomczynski et al., 1984).

\section{Epidermal growth factor ( $E G F$ )}

Extraction of mouse submaxillary gland and of human urine led independently to the purification of two polypeptides, mouse EGF and urogastrone, respectively. Structural studies showed them to be homologous, with 53 amino acid residues. A variety of biological activities has been demonstrated for EGF and it is widely distributed among species (Hollenberg, 1979).

Most of the evidence of a role for epidermal growth factor in mammary development comes from studies in the mouse. Receptors for EGF have been detected in normal mouse mammary gland (Taketani \& Oka, 1983a) and shown to vary with physiological state (Edery et al., 1985). One class of specific high affinity receptors for EGF $\left(K_{\mathrm{d}} 5.7 \times 10^{-11} \mathrm{M}\right)$ was detected in dissociated mammary epithelial cells from virgin mice and in membrane fractions. A second class of high affinity receptors $\left(K_{\mathrm{d}} 5 \times 10^{-10} \mathrm{M}\right)$, seen only in mammary gland membrane fractions, may be associated with stroma. From weaning there was a decline in levels of receptor binding with increasing age to the lowest levels in lactation, but with a marked increase between Days 5 and 10 of pregnancy, roughly paralleling the proliferative activity of the gland. Thyroid hormone (Vonderhaar et al., 1986) and progesterone (Murphy et al., 1988) may be involved in EGF receptor control.

Turkington (1969) demonstrated an effect of physiological concentrations of EGF on DNA synthesis in explants of mouse mammary tumours. Subsequently, a number of studies in vitro and in vivo have shown stimulation of proliferation of mammary cells in response to EGF. In cultures of whole mammary glands from oestrogen-progesterone-primed mice, lobulo-alveolar development occurred in response to insulin + prolactin + aldosterone + hydrocortisone, but if the gland was then allowed to involute, the redevelopment of lobulo-alveolar structures required the presence of EGF as well (Tonelli \& Sorof, 1980). Stimulation by EGF of DNA synthesis, or increase in cell number, has been observed in cultures of mouse and human mammary epithelial cells. However, EGF appears to have little mitogenic effect alone, being stimulatory when in the presence of other factors such as insulin, IGF-I, cholera toxin (which raises intracellular cyclic AMP concentrations) 
and fibroblast feeder layers (Stoker et al., 1976; Taylor-Papadimitriou et al., 1977; Taketani \& Oka, 1983a, b; Imagawa et al., 1986). In vivo, the local implantation of EGF stimulates lobulo-alveolar development of mouse mammary gland in oestrogen-progesterone-primed mice (Vonderhaar, 1987; Silberstein \& Daniel, 1987). The incidence of tumour development from MCF-7 cells implanted into athymic ovariectomized mice was increased by EGF administration (Dickson et al., 1986).

In addition to the positive effects on proliferation, EGF may affect functional differentiation of mammary gland. Taketani \& Oka (1983a) observed dose-dependent inhibition of casein synthesis by EGF in mouse mammary cells cultured with insulin + cortisol + prolactin. Subsequent studies have shown EGF to have bifunctional activity with respect to casein gene expression in vitro (Vonderhaar \& Nakhasi, 1986). In the presence of insulin, aldosterone and corticosterone, EGF increased messenger RNA for $\beta$ - and $\kappa$-casein in explants of mammary gland from pregnant mice. In rats only $\kappa$-casein mRNA was affected. When prolactin was also present, EGF became inhibitory to casein gene expression in tissues from pregnant and virgin rats and mice. However, Sankaran \& Topper (1987) found EGF to be inhibitory to casein synthesis only in the presence of high insulin concentrations and suggest that it is not an inhibitor in vivo. Indeed, levels of EGF in circulation and of mammary EGF receptors are not consistent with a role as an inhibitor of milk synthesis in the mouse.

The action of EGF on proliferation may be mediated in part by an action on type IV collagen synthesis. This component of the basal lamina is important for normal mammary development. Rat mammary cells require EGF + glucocorticoids for proliferation on plastic or type I collagen, but plating onto type IV collagen eliminates this need (Salomon et al., 1981).

Rall et al. (1985) have detected prepro-EGF messenger RNA in normal lactating mouse mammary gland. Conditioned medium from human breast cancer cell lines contains activity related to transforming growth factor- $\alpha$ (TGF- $\alpha$ ) (Dickson \& Lippman, 1987). The transforming growth factors are characterized by their ability to induce reversibly anchorage-dependent growth in soft agar, to reduce serum requirement and cause loss of contact inhibition in normal, nonneoplastic cells. TGF- $\alpha$ has a molecular weight of 5400 , is closely related to EGF and acts via the EGF receptor. TGF- $\alpha$ activities also occur in human milk and human mammary tumours (Salomon et al., 1984; Zwiebel et al., 1986) and in bovine mammary epithelium (Eckert et al., 1985). A local effect of TGF- $\alpha$ on lobulo-alveolar development in virgin female mice is reported by Vonderhaar (1987). The response was similar to that produced by EGF but the gland was more sensitive to TGF- $\alpha$, which acted at lower dose levels and in the absence of exogenous oestrogen/ progesterone priming. Stimulation of TGF- $\alpha$ production by oestradiol occurs in breast cancer cell lines (Dickson \& Lippman, 1987).

There is some evidence from in-vivo studies supporting a role for EGF in mammary growth. Okamato \& Oka (1984) found that removal of the submandibular salivary glands (sialoadenectomy) of virgin mice impaired their subsequent ability to raise large litters. Sheffield \& Welsch (1987) observed reduced mammary development and a reduced response to oestrogen + progesterone treatment in sialoadenectomized mice, effects which could be partly reversed by grafts of submandibular salivary gland or injection of EGF. Circulating plasma EGF shows circadian variation and is higher between 24:00 and 08:00 $\mathrm{h}$ in intact pregnant and lactating mice than in virgin mice. The elevation persists after the young are weaned and is abolished by sialoadenectomy (Kurachi \& Oka, 1985; Sheffield \& Welsch, 1987). However, sialoadenectomy does not alter urinary EGF concentrations (Kurachi \& Oka, 1985).

\section{Other growth factors}

A group of growth factors has been recognized, all with a strong affinity for heparin and including factors which stimulate angiogenesis. Two sub-classes have been identified: Class 1 anionic mitogens, including acidic brain fibroblast growth factor (FGF), molecular weight 15 000-17 000, 
and Class 2 cationic mitogens including basic pituitary FGF, molecular weights 18 000-20000 (Lobb et al., 1986). Bovine pituitary FGF stimulated the growth of cloned rat mammary myoepithelial and stromal cell lines in culture (Smith et al., 1984) and also T-47D human breast cancer cells (Dembinski \& Shiu, 1987). Rowe et al. (1986) have purified a related growth factor from human mammary tumour.

An activity related to platelet-derived growth factor (PDGF) is secreted by many breast cancer cell lines, although they appear not to contain a PDGF receptor (Dickson \& Lippman, 1987). PDGF is the major growth factor in serum, derived from platelets and is a heterodimer of a 14000 18000 molecular weight A chain and a 16000 molecular weight B chain. It is a potent mitogen for mesenchymal cells (Deuel et al., 1987).

Bano et al. (1985) have identified in human mammary tumours and milk a growth factor (mammary-derived growth factor-1, MDGF-1) which has properties distinguishing it from other known growth factors. It has a molecular weight of 62000 and a pI of $4 \cdot 8$. It binds to receptors on normal mouse mammary epithelium.

Not all growth factors are stimulatory. Breast cancer cell lines contain a receptor for and secrete activity related to transforming growth factor- $\beta$ (TGF- $\beta$ ) (Dickson \& Lippman, 1987). TGF- $\beta$ is a homodimer with a molecular weight of 25000 , which stimulates growth of fibroblastic cells, possibly indirectly through production of PDGF-like activity, but the proliferation of epithelial cells, including breast cancer cell lines, is inhibited by TGF- $\beta$ (Knabbe et al., 1987; Moses $e t$ al., 1987). Bohmer et al. (1987) have isolated another unrelated polypeptide growth inhibitor from bovine mammary gland, which shows immunological similarity to a heart fatty acid binding protein.

\section{Growth factors in milk}

Stimulation of DNA synthesis by factors in human milk was first reported by Klagsbrun (1978). Subsequent studies have shown that milk, and especially colostrum, contains high concentrations of a variety of polypeptide growth factors (Read, 1988). There are considerable differences between species in the presence, or concentration, of milk growth factors. In human and mouse milk, EGF is the major mitogen and EGF concentrations in human milk are many times higher than in plasma (Carpenter, 1980). In ruminant milk, EGF could not be detected and the major growth factor activity is colostric basic growth factor, structurally related to PDGF (Brown \& Blakeley, 1984). Other growth factors identified in milk include IGF-I and TGF- $\alpha$ (see Read, 1988, for review). The origins of milk growth factors are largely unknown and probably represent both transfer from serum and in some instances local synthesis. The physiological significance is also uncertain. An essential role in the neonate is unlikely, but actions on gut tissues have been demonstrated. The presence of growth factors in milk might also reflect actions in the mammary gland. This remains to be demonstrated with certainty.

\section{Conclusions}

There is as yet no definitive evidence of growth factor involvement in mammary function. Nevertheless, the increasing evidence that normal mammary cells as well as certain cell lines contain receptors for, and can respond to, growth factors provides a basis for future experimentation. The presence of growth factors in milk and in mammary extracts and conditioned medium, together with demonstrations of messenger RNA for growth factors in normal (Rall et al., 1985; Murphy et al., 1987) as well as neoplastic tissues and cell lines, may argue for autocrine and paracrine, as well as endocrine, modes of action. Growth factors may provide the means of reconciling the findings of in-vivo and in-vitro studies especially with relation to mammary gland growth. Nutritional modulation of growth factor as well as hormones may help to explain the hitherto 
poorly understood effects of both underfeeding and overnutrition on mammary development, and which cannot be explained simply in terms of nutrient supply.

A model system based on rat fibroblasts has identified restriction points in the cell cycle, which can be overcome by sequential actions of growth factors. PDGF acts as a competence factor early in $\mathrm{G}_{1}$. EGF (or TGF- $\alpha$ ), and then IGF-I, act later as progression factors, allowing competent cells to traverse $G_{1}$ and enter $S$ phase (see Pledger et al., 1982). It remains to be seen whether mammary cells similarly require the co-operative actions of a number of growth factors to traverse the cell cycle.

\section{References}

Adams, S.O., Nissley, S.P., Handwerger, S. \& Rechler, M.M. (1983) Developmental patterns of insulin growth factor-I and -II synthesis and regulation in rat fibroblasts. Nature, Lond. 302, 150-153.

Akers, R.M. (1985) Lactogenic hormones; binding sites, mammary growth, secretory cell differentiation, and milk biosynthesis in ruminants. J. Dairy Sci. 68, 50I-519.

Banerjee, M.R. \& Antoniou, M. (1984) Serum-free culture of the isolated whole mammary organ of the mouse: a model for the study of differentiation and carcinogenesis. In Methods for Serum-Free Culture of Cells of the Endocrine System, pp. 143-169. Eds D. W. Barnes, D. A. Sirbasku \& G. H. Sato. Alan R. Liss, New York.

Bano, M., Salomon, D.S. \& Kidwell, W.R. (1985) Purification of a mammary-derived growth factor from human milk and human mammary tumors. J. biol. Chem. 260, 5745-5752.

Beck, J.C. \& Hosick, H.L. (1988) Growth of mouse mammary epithelium in response to serum-free media conditioned by mammary adipose tissue. Cell Biol. Int. Rep. 12, 85-97.

Berthois, Y., Katzenellenbogen, J.A. \& Katzenellenbogen, B.S. (1986) Phenol red in tissue culture media is a weak estrogen: implications concerning the study of estrogen-responsive cells in culture. Proc. natn. Acad. Sci. U.S.A. 83, 2496-2500.

Bettgar, W.J. \& McKeehan, W.L. (1986) Mechanisms of cellular nutrition. Physiol. Rev. 66, 1-35.

Blundell, T.L. \& Humbel, R.E. (1980) Hormone families: pancratic hormones and homologous growth factors. Nature, Lond. 287, 781-787.

Bohmer, F.-D., Sun, Q., Peppetle, M., Muller, T., Eriksson, V., Wang, J.L. \& Grosse, R. (1987) Antibodies against mammary derived growth inhibitor (MDGI) react with a fibroblast growth inhibitor and heart fatty acid binding protein. Biochem. Biophys. Res. Commun.148, 1425-1431.

Bolander, F.F., Nicholas, K.R., VanWyk, J.J. \& Topper, Y.J. (1981) Insulin is essential for accumulation of casein mRNA in mouse mammary epithelial cells. Proc. natn. Acad. Sci. U.S.A. 78, 5682-5684.

Brown, K.D. \& Blakeley, D.M. (1984) Partial purification and characterization of a growth factor present in goat's colostrum. Similarities with platelet-derived growth factor. Biochem. J. 219, 609-617.

Campbell, P.G. \& Baumrucker, C.R. (1986) Characterization of insulin-like growth factor-1/somatomedin $\mathrm{C}$ receptors in the bovine mammary gland. J. Dairy Sci. 69, Suppl. 1, 218G, Abstr.
Campbell, P.G., Frey, D.M. \& Baumrucker, C.R. (1987) Changes in bovine mammary insulin binding during pregnancy and lactation. Comp. Biochem. Physiol. 87B, 649-653.

Carpenter, G. (1980) EGF is a major growth-promoting agent in human milk. Science, N.Y. 210, 198-199.

Chomczynski, P., Qasba, P. \& Topper, Y.J. (1984) Essential role of insulin in the transcription of the rat 25000 molecular weight casein gene. Science, N.Y. 226, 1326-1328.

Cowie, A.T., Forsyth, I.A. \& Hart, I.C. (1980) Hormonal Control of Lactation. Springer Verlag, Berlin.

Daughaday, W.H., Hall, K., Salmon, W.D., Van den Brande, J.L. \& Van Wyk, J.J. (1987) On the nomenclature of the somatomedins and insulinlike growth factors. J. clin. Endocr. Metab. 65, 1075-1076.

DeLeon, D.D., Bakker, B., Wilson, D.M., Hintz, R.L. \& Rosenfeld, R.G. (1988) Demonstration of insulin-like growth factor (IGF-I and II) receptors and binding protein in human breast cancer cell lines. Biochem. Biophys. Res. Commun. 152, 398-405.

Dembinski, T.C. \& Shiu, R.P.C. (1987) Growth factors in mammary gland development and function. In The Mammary Gland, Development, Regulation and Function, pp. 355-381. Eds M. C. Neville \& C. W. Daniel. Plenum Press, New York.

Dembinski, T.C., Leung, C.K.H. \& Shiu, R.P.C. (1985) Evidence for a novel pituitary factor that potentiates the mitogenic effect of estrogen in human breast cancer cells. Cancer Res. 45, 3083-3089.

DeOme, K.B., Faulkin, L.S., Bern, H.A. \& Blair, P.B. (1959) Development of mammary tumors from hyperplastic alveolar nodules transplanted into gland-free mammary fat pads of female $\mathrm{C} 3 \mathrm{H}$ mice. Cancer Res. 19, 515-520.

Deuel, T.F., Pierce, G.F., Yeh, H-J., Shawver, L.K., Milner, P.G. \& Kimura, A. (1987) Platelet-derived growth factor/sis in normal and neoplastic growth. $J$. cell. Physiol., Suppl. 5, 95-99.

Dickson, R.B. \& Lippman, M.E. (1987) Estrogenic regulation of growth and polypeptide growth factor secretion in human breast carcinoma. Endocr. Rev. 8, $29-43$.

Dickson, R.B., McManaway, M.E. \& Lippman, M.E. (1986) Estrogen-induced factors of breast cancer cells can partially replace estrogen to promote tumor growth. Science, N.Y. 232, 1540-1543.

Disenhaus, C., Belair, L. \& Djiane, J. (1988) Caractérisation et évolution physiologique des récepteurs pour les "insulin-like growth factors" I et II (IGFs) dans la 
glande mammaire de brebis. Reprod. Nutr. Dévelop. 28, 241-252.

Eckert, K., Lubbe, L., Schon, R. \& Grosse, R. (1985) Demonstration of transforming growth factor activity in mammary epithelial tissues. Biochem. Int. 11, 441-451.

Edery, M., Pang, K., Larson, L., Colosi, T. \& Nandi, S. (1985) Epidermal growth factor receptor levels in mouse mammary glands in various physiological states. Endocrinology 117, 405-411.

Emerman, J.T. \& Pitelka, D.R. (1977) Maintenance and induction of morphological differentiation in dissociated mammary epithelium on floating collagen membranes. In Vitro 13, 316-328.

Emerman, J.T., Enami, J., Pitelka, D.R. \& Nandi, S. (1977) Hormonal effects on intracellular and secreted casein in cultures of mouse mammary epithelial cells on floating collagen membranes. Proc. natn. Acad. Sci. U.S.A. 74, 4466-4470.

Forsyth, I.A. (1983) The endocrinology of lactation. In Biochemistry of Lactation, pp. 309-349. Ed. T. B. Mepham. Elsevier, Amsterdam.

Forsyth, I.A. (1986) Variation among species in the endocrine control of mammary growth and function: the roles of prolactin, growth hormone and placental lactogen. J. Dairy Sci. 69, 886-903.

Furlanetto, R.W. \& DiCarlo, J.N. (1984) Somatomedin$C$ receptors and growth effects in human breast cells maintained in long-term tissue culture. Cancer Res. 44, 2122-2128.

Hammond, S.L., Ham, R.G. \& Stampfer, M.R. (1984) Serum-free growth of human mammary epithelial cells: rapid clonal growth in defined medium and extended serial passage with pituitary extract. Proc. natn. Acad. Sci. U.S.A. 81, 5435-5439.

Hollenberg, H.D. (1979) Epidermal growth factorurogastrone, a polypeptide acquiring hormonal status. Vitams Horm. 37, 69-110.

Hoshino, K. \& Martin, F. (1974) Parenchymal-stromal interactions during regeneration of mammary isografts in mice. Anat. Rec. 178, 379.

Houdebine, L-M., Djiane, J., Dusanter-Fourt, I., Martel, P., Kelly, P.A., Devinoy, E. \& Servely, J-L. (1985) Hormonal action controlling mammary activity. $J$. Dairy Sci. 68, 489-500.

Ichinose, R.R. \& Nandi, S. (1966) Influence of hormones on lobulo-alveolar differentiation of mouse mammary glands in vitro. $J$. Endocr. 35, 331-340.

Imagawa, W., Tomooka, Y. \& Nandi, S. (1982) Serumfree growth of normal and tumor mouse mammary epithelial cells in primary culture. Proc. natn. Acad. Sci. U.S.A. 79, 4074-4077.

Imagawa, W., Spencer, E.M., Larson, L. \& Nandi, S. (1986) Somatomedin-C substitutes for insulin for the growth of mammary epithelial cells from normal virgin mice in serum-free collagen gel culture. Endocrinology 119, 2695-2699.

Jacobsohn, D. (1961) Hormonal regulation of mammary gland growth. In Milk: the Mammary Gland and its Secretion, pp. 127-160. Eds S. K. Kon \& A. T. Cowie. Academic Press, New York.

Johnsson, I.D. \& Hart, I.C. (1986) Manipulation of milk yield with growth hormone. In Recent Advances in Animal Nutrition, pp. 105-123. Eds W. Haresign \& D. J. A. Cole. Butterworths, London.
Kano-Sueoka, T., Cohen, D.M. \& Yamaizumi, Z. (1979) Phosphoethanalanine as a growth factor of a mammary carcinoma cell line of rat. Proc. natn. Acad. Sci. U.S.A. 76, 574I-5744.

Kidwell, W.R., Knazek, R.A., Vonderhaar, B.K. \& Losconczy, I. (1982) Effects of unsaturated fatty acids on the development and proliferation of normal and neoplastic breast epithelium. In Molecular Interactions of Nutrition and Cancer, pp. 219-239. Eds M. S. Arnott, J. van Eys, Y-M. Yang. Raven Press, New York.

Klagsbrun, M. (1978) Human milk stimulates DNA synthesis and cellular proliferation in cultured fibroblasts. Proc. natn. Acad. Sci. U.S.A. 75, 5057-5061.

Knabbe, C., Lippman, M.E., Wakefield, L.M., Flanders, K.C., Kasid, A., Derynck, R. \& Dickson, R.B. (1987) Evidence that transforming growth factor $\beta$ is a hormonally regulated growth factor in human breast cancer cells. Cell $\mathbf{4 8}, 417-428$.

Knight, C.H. (1984) Mammary growth and development: strategies of animals and investigators. Symp. zool. Soc. Lond. 51, 147-170.

Knight, C.H. \& Wilde, C.J. (1987) Mammary growth during lactation: implications for increasing milk yield. J. Dairy Sci. 70, 1991-2000.

Kurachi, H. \& Oka, T. (1985) Changes in epidermal growth factor concentrations of submandibular gland, plasma and urine of normal and sialoadenectomized female mice during various reproductive stages. J. Endocr. 106, 197-202.

Lee, E.Y.-H., Parry, G. \& Bissell, M.J. (1984) Modulation of secreted proteins of mouse mammary epithelial cells by the collagenous substrata. J. Cell Biol. 98, 146-155.

Levine, J.F. \& Stockdale, F.E. (1984) 3T3-Li adipocytes promote the growth of mammary epithelium. Expl Cell Res. 151, 112-122.

Lobb, R., Sasse, J., Sullivan, R., Shing, Y., D'Amore, P., Jacobs, J. \& Klagsbrun, M. (1986) Purification and characterization of heparin-binding endothelial cell growth factors. J. biol. Chem. 261, 1924-1928.

Lyons, W.R. (1942) The direct mammotrophic action of mammotrophic hormone. Proc. Soc. exp. Biol. Med. 51, 308-311.

Lyons, W.R. (1958) Hormonal synergism in mammary growth. Proc. R. Soc. B 149, 303-325.

Mackenzie, D.D.S., Forsyth, I.A., Brooker, B.E. \& Turvey, A. (1982) Culture of bovine mammary epithelial cells on collagen gels. Tissue \& Cell 14, 231-241.

Massague, J. \& Czech, M.P. (1982) The subunit structures of 2 distinct receptors for insulin-like growth factors I and II and their relationship to the insulin receptor. J. biol. Chem. 257, 5038-5045.

McGrath, M.F. (1987) A novel system for mammary epithelial cell culture. J. Dairy Sci. 70, 1967-1980.

McManus, M.J. \& Welsch, C.W. (1984) Hormoneinduced ductal DNA synthesis of human breast tissues maintained in athymic nude mice. Cancer Res. 41, 3300-3305.

Mepham, T.B. (Ed.) (1983) Biochemistry of Lactation. Elsevier, Amsterdam.

Moses, H.L., Coffey, R.J., Leof, E.B., Lyons, R.M. \& Keski-Oja, J. (1987) Transforming growth factor- $\beta$ 
regulation of cell proliferation. J. cell. Physiol. Suppl. $5,1-7$.

Murphy, L.C., Murphy, L.J. \& Shiu, R.C. (1988) Progestin regulation of EGF-receptor mRNA accumulation in T-47D human breast cancer cells. Biochem. Biophys. Res. Commun. 150, 192-196.

Murphy, L.J., Bell, G.I. \& Friesen, H.G. (1987) Tissue distribution of insulin-like growth factor I and II messenger ribonucleic acid in the adult rat. Endocrinology 120, 1279-1282.

Myal, Y., Shiu, R.P.C., Bhaumick, B. \& Bala, M. (1984) Receptor binding and growth-promoting activity of insulin-like growth factors in human breast cancer cells (T-47D) in culture. Cancer Res. 44, 5486-5490.

Nandi, S. (1959) Hormonal control of mammogenesis and lactogenesis in the $\mathrm{C} 3 \mathrm{H} / \mathrm{He} \mathrm{Crgl}$ mouse. Univ. Calif. Publs Zool. 65, 1-128.

Nicoll, C.S., Anderson, T.R., Herbert, N.J. \& Russell, S.M. (1987) Prolactin, growth factors and cell growth. In Actions of Prolactin on Molecular Processes, pp. 200-212. Ed. J. A. Rillema. CRC Press, Boca Raton.

Norgren, A. (1968) Modification of mammary development in rabbits injected with ovarian hormones. Acta Univ. Lund. Sect. 2, 4-42.

Oka, T. \& Yoshimura, M. (1986) Paracrine regulation of mammary gland growth. Clinics Endocrinol. Metab. $15,79-97$.

Okamoto, S. \& Oka, T. (1984) Evidence for physiological function of epidermal growth factor: pregestational sialoadenectomy decreases milk production and increases offspring mortality during lactation period. Proc. natn. Acad. Sci. U.S.A. 81, 6059-6063.

Parry, G., Cullen, B., Kaetzel, C.S., Kramer, R. \& Moss, L. (1987) Regulation of differentiation and polarized secretion in mammary epithelial cells maintained in culture: extracellular matrix and membrane polarity influences. J. Cell Biol. 105, 2043-2051.

Peel, C.J. \& Bauman, D.E. (1987) Somatotropin and lactation. J. Dairy Sci. 70, 474-486.

Pledger, W.J., Leof, E.B., Chou, B.B., Olashaw, N., O'Keefe, E.J., Van Wyk, J.J. \& Wharton, W.R. (1982) Initiation of cell-cycle traverse by serumderived growth factors. In Growth of Cells in Hormonally Defined Media, pp. 259-273. Eds G. H. Sato, A. B. Pardee \& D. A. Sirbasku. Cold Spring Harbor Laboratory.

Posner, B.I., Kelly, P.A., Shiu, R.P.C. \& Friesen, H.G. (1974) Studies of insulin, growth hormone and prolactin binding: tissue distribution, species variation and characterization. Endocrinology 95, 521-531.

Prosser, C.G. \& Topper, Y.J. (1986) Changes in the rate of carrier-mediated glucose transport by mouse mammary epithelial cells during ontogeny: hormone dependence delineated in vitro. Endocrinology 119, 91-96.

Prosser, C.G., Fleet, I.R., Corps, A.N., Heap, R.B. \& Froesch, E.R. (1988) Increased milk secretion and mammary blood flow during close-arterial infusion of insulin-like growth factor 1 (IGF-1) into the mammary gland of the goat. J. Endocr. 117 (Suppl.) 248, Abstr.

Rall, L.R., Scott, J. \& Bell, G.I. (1985) Mouse preproepidermal growth factor synthesis by the kidney and other tissues. Nature, Lond. 313, 228-231.
Read, L.C. (1988) Milk growth factors. In Fetal and Neonatal Growth, pp. 131-152. Ed. F. Cockburn. John Wiley, New York.

Riss, T.L. \& Sirbasku, D.A. (1987) Purification and identification of transferrin as a major pituitary-derived mitogen for MTW9/PL2 rat mammary tumor cells. In Vitro 23, 841-849.

Rivera, E.M. \& Bern, H.A. (1961) Influence of insulin on maintenance and secretory stimulation of mouse mammary tissues by hormones in organ-culture. Endocrinology 69, 340-353.

Rosen, J.M. (1987) Milk protein gene structure and expression. In The Mammary Gland: Development Regulation and Function, pp. 301-322. Eds M. C. Neville \& C. Daniel. Plenum Press, New York.

Rowe, J.M., Kasper, S., Shui, R.P.C. \& Friesen, H.G. (1986) Purification and characterization of a human mammary tumor-derived growth factor. Cancer Res. 46, 1408-1412.

Salmon, W.D. \& Daughaday, W.H. (1957) A hormonally controlled serum factor which stimulates sulfate incorporation by cartilage in vitro. J. Lab. clin. Med. 49, 825-836.

Salomon, D.S., Liotta, L.A. \& Kidwell, W.R. (1981) Differential response to growth factors by rat mammary epithelium plated on different collagen substrata in serum-free medium. Proc. natn. Acad. Sci. U.S.A. 78, 382-386.

Salomon, D.S., Zwiebel, J.A., Bano, M., Losonczy, I., Fehnel, P. \& Kidwell, W.R. (1984) Presence of transforming growth factors in human breast cancer cell. Cancer Res. 44, 4069-4077.

Sankaran, L. \& Topper, Y.J. (1987) Is EGF a physiological inhibitor of mouse mammary casein synthesis? Unphysiological responses to pharmacological levels of hormones. Biochem. Biophys. Res. Commun. 146, $121-125$.

Sheffield, L.G. \& Welsch, C.W. (1986) Transplantation of bovine mammary tissue to athymic nude mice: growth subcutaneously and in mammary gland-free fat pads. J. Dairy Sci. 69, 1141-1147.

Sheffield, L.G. \& Welsch, C.W. (1987) Influence of submandibular salivary glands on hormone responsiveness of mouse mammary glands. Proc. Soc. exp. Biol. Med. 186, 368-377.

Silberstein, G.B. \& Daniel, C.W. (1987) Investigation of mouse mammary ductal growth regulation using slow-release plastic implants. J. Dairy Sci. 70, 1981-1990.

Sirbasku, D.A. (1978) Estrogen-induction of growth factors specific for hormone-responsive mammary, pituitary and kidney tumor cells. Proc. natn. Acad. Sci. U.S.A. 75, 3786-3790.

Skarda, J., Urbanova, E. \& Bilek, J. (1977) Changes in insulin and prolactin responsiveness of goat mammary tissue during ontogenesis and pregnancy. Endocr. exp. 11, 105 113.

Smith, J.A., Winslow, D.P. \& Rudland, P.S. (1984) Different growth factors stimulate cell division of rat mammary epithelial, myoepithelial and stromal cell lines in culture. J. cell. Physiol. 119, 320-326.

Soto, A.M. \& Sonnenschein, C. (1987) Cell proliferation of estrogen-sensitive cells: the case for negative control. Endocr. Rev. 8, 44-52.

Soule, H. \& McGrath, C.M. (1980) Estrogen responsive 
proliferation of clonal human breast carcinoma cells in athymic mice. Cancer Lett. 10, 177-189.

Stockdale, F.E., Juergens, W.G. \& Topper, Y.J. (1966) A histological and biochemical study of hormonedependent differentiation of mammary gland tissue in vitro. Devl Biol. 13, 266-381.

Stoker, M.P.G., Pigott, D. \& Taylor-Papadimitriou, J. (1976) Response to epidermal growth factor of cultured human mammary epithelial cells from benign tumours. Nature, Lond. 264, 764-765.

Taketani, Y. \& Oka, T. (1983a) Biological action of epidermal growth factor and its functional receptors in normal mammary epithelial cells. Proc. natn. Acad. Sci. U.S.A. 80, 2647-2650.

Taketani, Y. \& Oka, T. (1983b) Epidermal growth factor stimulates cell proliferation and inhibits functional differentiation of mouse mammary epithelial cells in culture. Endocrinology 113, 871-877.

Taylor-Papadimitriou, J., Shearer, M. \& Stoker, M.G.P. (1977) Growth requirements of human mammary epithelial cells in culture. Int. J. Cancer 20,903-908.

Thordarson, G. \& Talamantes, F. (1987) The role of the placenta in mammary gland development and function. In The Mammary Gland: Development, Regulation and Function, pp. 459-498. Eds M. C. Neville \& C. Daniel. Plenum Press, New York.

Tonelli, Q.J. \& Sorof, S. (1980) Epidermal growth factor requirement for development of cultured mammary gland. Nature, Lond. 285, 250-252.

Topper, Y.J. \& Freeman, C.S. (1980) Multiple hormone interactions in the developmental biology of the mammary gland. Physiol. Rev. 60, 1049-1106.

Tucker, H.A. (1987) Quantitative estimates of mammary growth during various physiological states: a review. J. Dairy Sci. 70, 1958-1966.

Turkington, R.W. (1969) The role of epidermal growth factor in mammary development in vitro. Expl Cell Res. 57, 79-85.
Vonderhaar, B.K. (1987) Local effects of EGF, $\alpha$-TGF and EGF-like growth factors on lobulo-alveolar development in the mouse mammary gland in vivo. $J$. cell. Physiol. 132, 581-584.

Vonderhaar, B.K. \& Greco, A.E. (1979) Lobulo-alveolar development of mouse mammary glands is regulated by thyroid hormones. Endocrinology 104, 409-418.

Vonderhaar, B.K. \& Nakhasi, H.L. (1986) Bifunctional activity of epidermal growth factor on $\alpha$ - and $\kappa$ casein gene expression in rodent mammary glands in vitro. Endocrinology 119, 1178-1184.

Vonderhaar, B.K., Tang, E., Lyster, R.R. \& Nascimento, M.C.S. (1986) Thyroid hormone regulation of epidermal growth factor receptor levels in mouse mammary glands. Endocrinology 119, 580-585.

Wicha, M.S., Lowrie, G., Kohn, E., Bagavandoss, P. \& Mahn, T. (1982) Extracellular matrix promotes mammary epithelial growth and differentiation in vitro. Proc. natn. Acad. Sci. U.S.A. 79, 3213-3217.

Winder, S.J. \& Forsyth, I.A. (1986) Insulin-like growth factor 1 (IGF-1) is a potent mitogen for ovine mammary epithelial cells. J. Endocr. 108 (Suppl.), 141, Abstr.

Winder, S.J. \& Forsyth, I.A. (1987) Binding of insulinlike growth factor 1 (IGF-1) to ovine mammary epithelial microsomes. J. Endocr. 112 (Suppl.), 64, Abstr.

Yang, J., Richards, J., Guzman, R., Imagawa, W. \& Nandi, S. (1980) Sustained growth in primary culture of normal mammary epithelial cells embedded in collagen gels. Proc. natn. Acad. Sci. U.S.A. 77, 2088-2092.

Zwiebel, J.A., Bano, M., Nexo, E., Salomon, D.S. \& Kidwell, W.R. (1986) Partial purification of transforming growth factors from human milk. Cancer Res. 46, 933-939. 